\title{
ملحقات الموازنة العامة
}

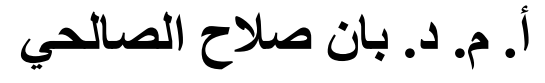

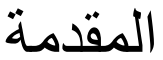

من الامور المألوفة في مضمون الموازنات العامة بيان النفقات والاير ادات

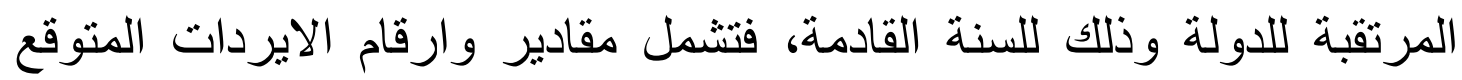
الحصول عليها والمبالغ المتوقع انفاقها ضمن تقسيمات متنو عة كالتقسيم الاداري التئي او الوظيفي واير اد بعض القو اعد العامة لتسهيل تطبيق وتتفيذ الموازنة العامة.

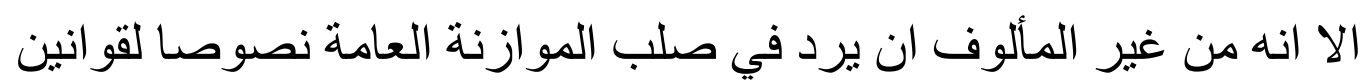

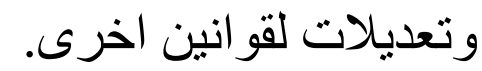

أي تتحول الموازنة العامة الى وسيلة او أداة لإير اد تعديلات على تشريعات

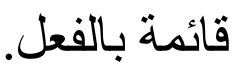

هنا يتبادر الى الذهن عدة تسأؤلات حول هذه طبيعة التعديلات او الملحقات؟

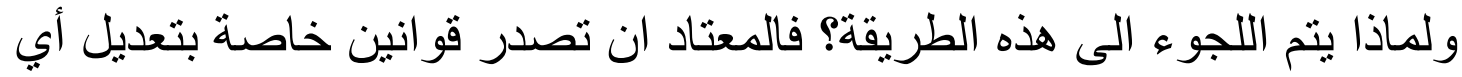
قانون، فلماذا الركون الى هذه الوسيلة ونكرار اللجوء اليها بحيث تؤدي في النهاية

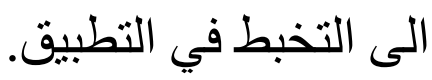

هذه الطريقة في تضمين الموازنة العامة يندر اللجوء اليها بشكل عام، فهل يوجد نص دستوري يبيح هذا الاسلوب او يحدد اجر اهه؟ او يحدد خطو ات التباعها.

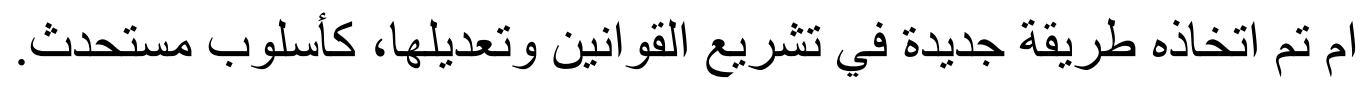

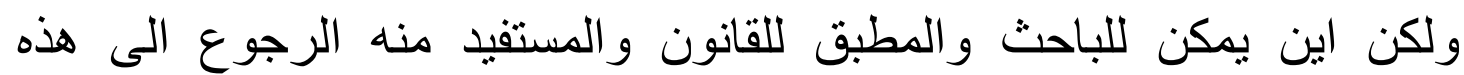

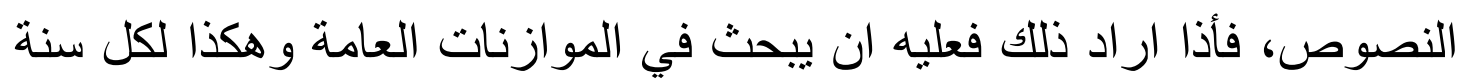
وبالتالي يظهر ما يثير الصعوبات و الاستفهامات العديدة. 
لذا نحاول في بحثنا المتواضع هذا ان نبين تكييف طبيعة هذه الملحقات

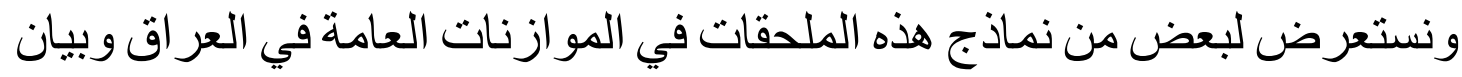
ما يعتري اتباع هذا الاسلوب من سلبيات.

\section{المبحث الاول \\ ماهية ملحقات الموازنة العامة}

لمعرفة ماهية ملحقات الموازنة العامة يسلزم الدخول في تحديد طبيعة

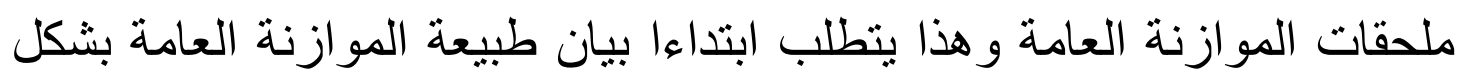

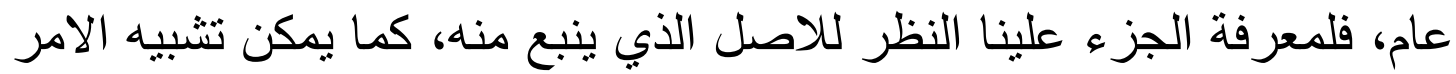

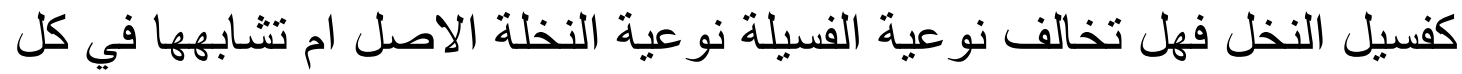
الصفات، و هذا ما سوف نحاول اكتثافه في هذا المبحث...

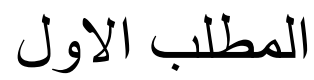

\section{الطبيعة القانونية للموازنة العامة}

سنحاول ايضاح طبيعة الموازنة العامة بشكل مختصر ، الحقيقة ان مصطلح

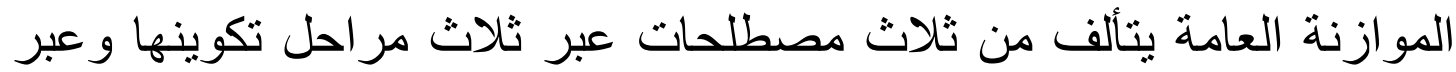
القواعد العامة في تمييز القواعد الادارية عن القانونية من النواحي الثكلية

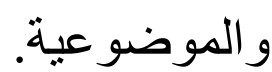

فهل تعد تثريعا من الناحية الثكلية و الموضو عية، هل تعد الموازنة بشكلها

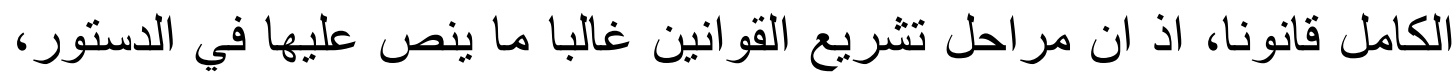
و المر احل الاعتيادية لاصدار أي قانون يتمثل بالاقتر اح من قبل التيل السلطة التنفيذية ابتداءا ثم المناقثة من قبل البرلمان و المصادقة عليه ثم النشر في الجريدة الرسمية. هذا ما يتم عموما في الدول النيابية، اذ تكون الموازنة العامة في البداية مجرد

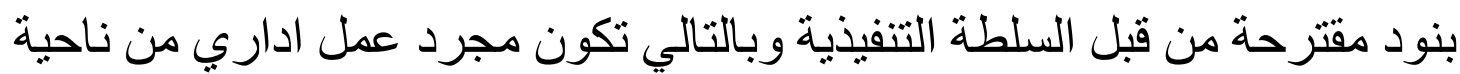

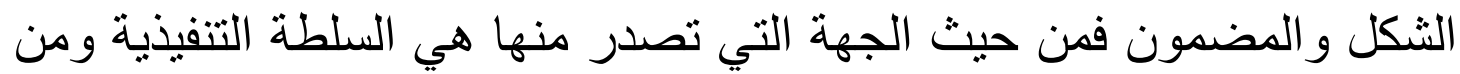

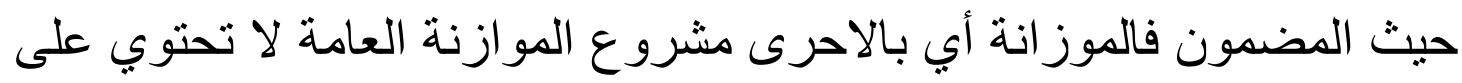

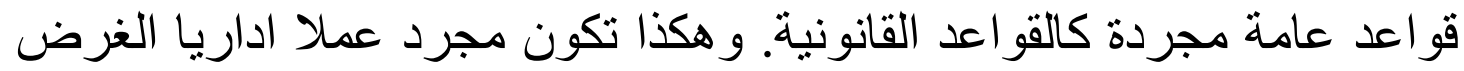


منه تنظيم الخرج و الدخل، طبقا للقوانين القائمة التي يقوم على اساسها تنظيم

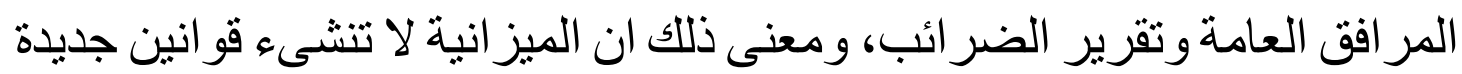

$$
\text { و انما هي برنامج للتنبير في حدود القوانين الموجودة. }
$$

تلحق هذه المرحلة أي مرحلة الاقتر اح مرحلة مهمة مرت بمر احل تطور

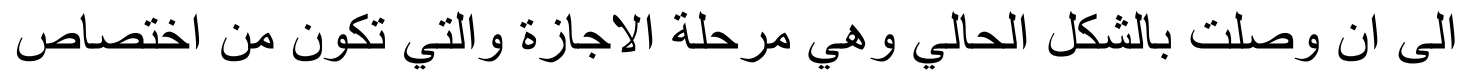

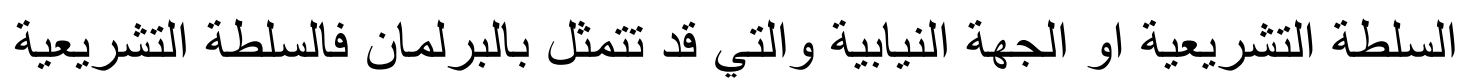
اختصاصان اساسيان: 1 ـ الاختصاص التشريعي الذي يقر بمقتضاه القوانين.

r-الاختصاص المالي الذي يقر بمقتضاه ميز انية الدولة. فلا تصبح الموازنة نافذة الا بعد تصديقها من قبل السلطة التشريعية،

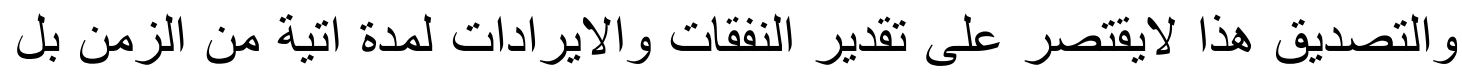

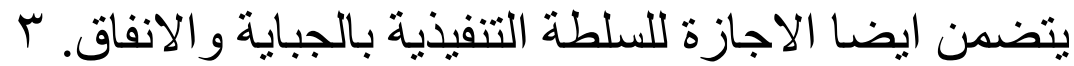
نلاحظ ان نظر السلطة التشريعية ومصادقتها للموازنة العامة تعد من الاسس

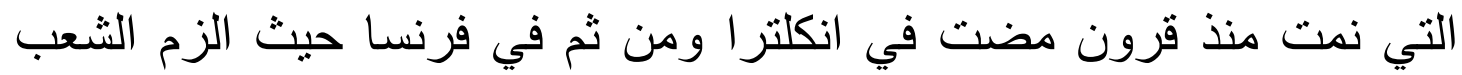
حصوله على موافقة ممثليه على فرض الضر ائب في البداية ثم على كيفية انفاق

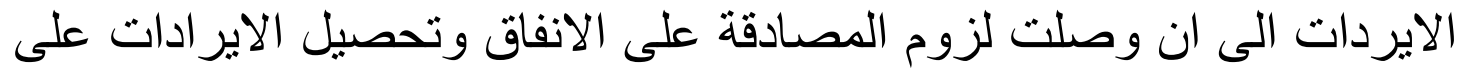
شكل موازنة عامة.

اما أصل الاجازة فيعود الى مبدأ سيادة وحقه في مر اقبة الاموال العمومية التي لايجوز التصرف بها الا بموافقة السلطة التشريعية التي تمثله وقد كرس هذدا فئه الحق في معظم الاحيان بموجب نصوص دستورية. ع اذ ان فكرة الموازنة العامة كمفهوم علمي حديث ارتبط ارتباطا وثيقا بوجود الدولة الحديثة القائمة على مبدأ الفصل بين السلطات، السلطة التنفيذية، السلطة التشريعية، السلطة القضائية.

فمن الملامح الرئيسية للموازنة العامة اعتمادها من السلطة التشريعية ومن

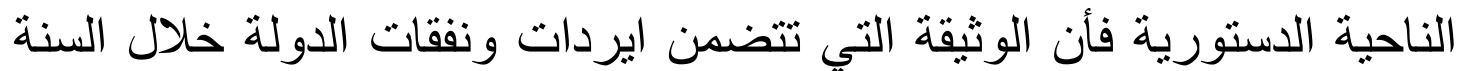
المقبلة، لاتسمى موازنة الا بعد اعتمادها من السلطة التشريعية وقبل ذلكية للك يطلق

$$
\text { عليها (مشروع موازنة). } 7
$$

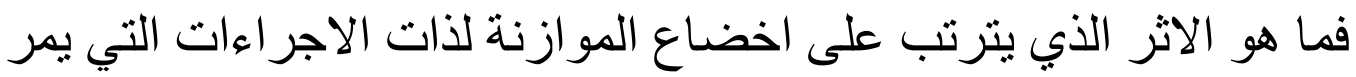

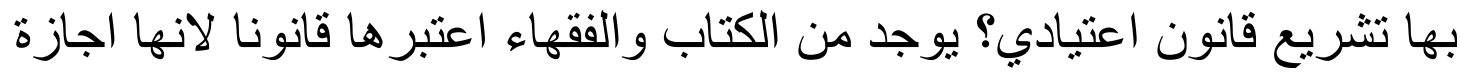


من السلطة التشريعية المشرعة لتنظيم نشاط الدولة المالي خلال الفترة الزمنية

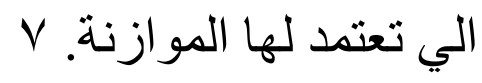

حيث ان الموازنة العامة من الناحية الادارية و التنظيمية تعد خطة عمل يتم

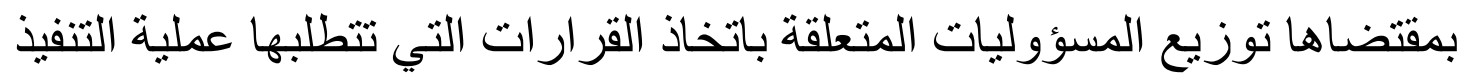

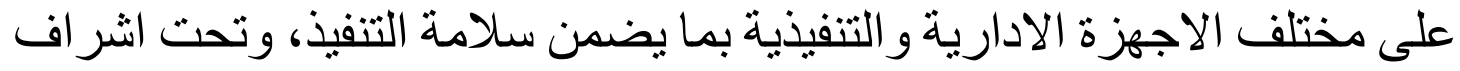
السلطة التشريعية الممثلة للشعب وبذلك بضمن الشعب عدم تجاوز السلطة التنفيذية للاعتمادات المقررة، وفق اوجه الانفاق المحددة، ويضمن كذلك تحصبل

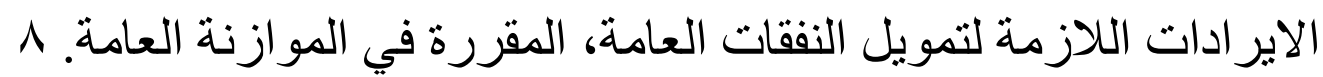
و الجدير بالذكر ان الكتاب قد اجمعو العلى أن قانون الموازنة العامة يعد

قانونا من الناحية الثكلية 9، و لايعتبر قانونا من الناحية الموضو عية، لماذا؟ لانه لايتضدن قو اعد عامة مجردة، مثل التي يتضدنها كل قانون بشكل عام

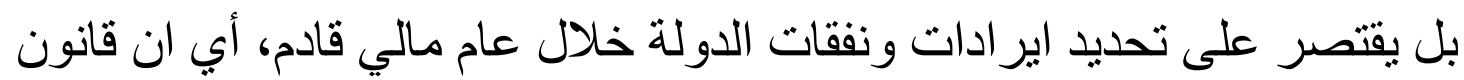
الموازنة العامة بعد من الناحية الموضو عية عملا تنفيذيا اداريا وماليا، فالموازنة العامة بطبيعتها عمل اداري ومالي يتخذ شكل القانون، ومن أهم اوجه الاختلاف

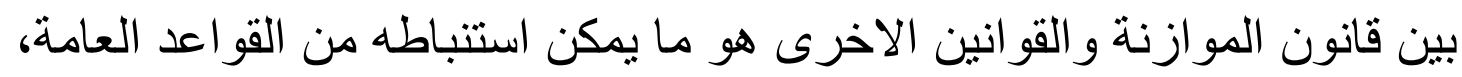

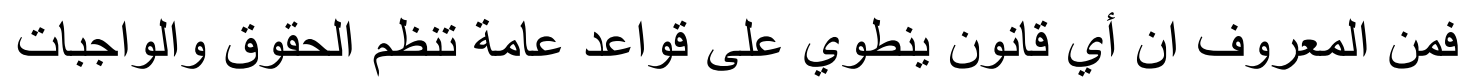

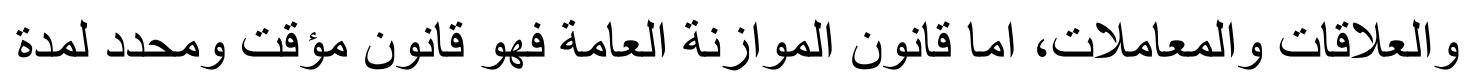

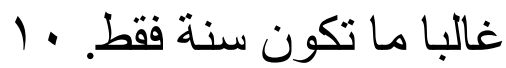

وبالتالي يكون قانون الموازنة العامة قانونا بالمعنى العضوي أو الثكلي فقط التطا لكونه صـادر ا من السلطة المختصة بالتشريع، ولقد أكدت محكمة القضاء الاداري

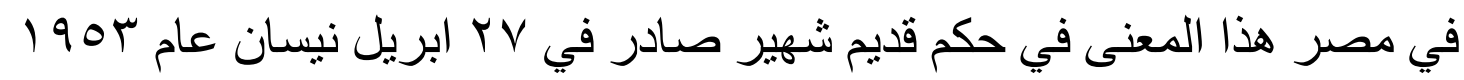

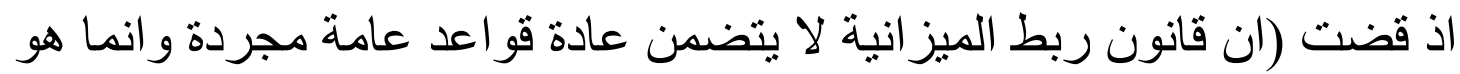
تحديد للاير ادات من مصادر ها وتوزيع لها على مصار فئها العامة بما يكفل سير

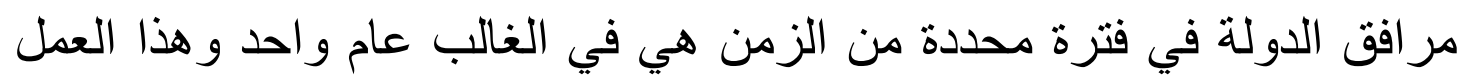

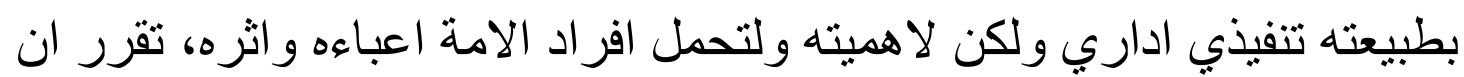
يصدر عن السلطة التشريعية التي تمثل ار ادة الامة، ولما كانت اغلب ولب اعلى اعمال

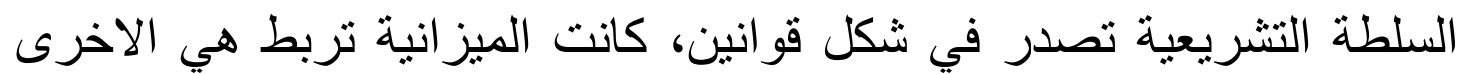




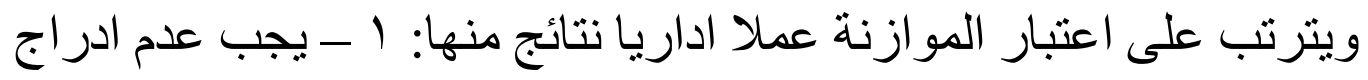

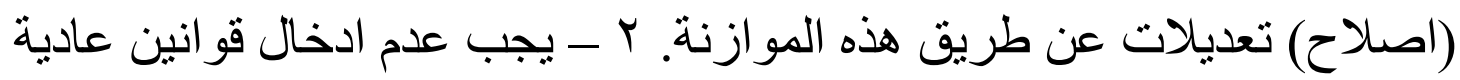

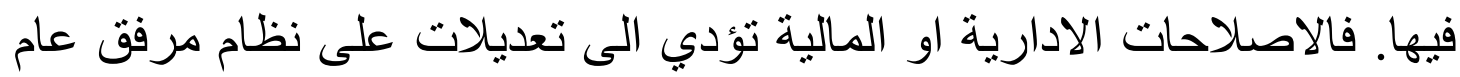

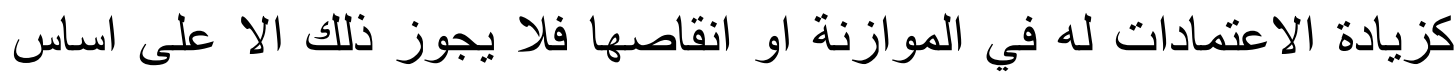

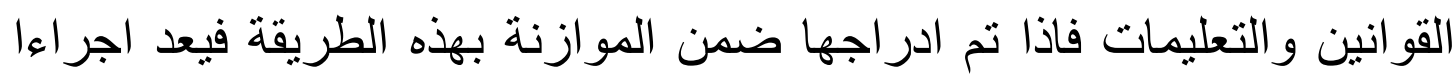

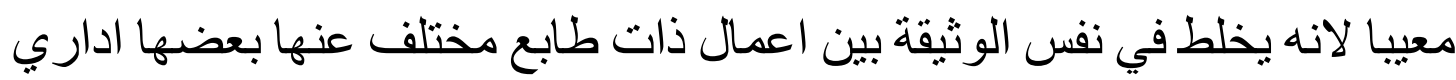

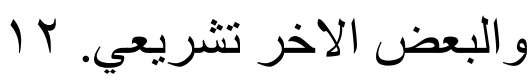

\section{المطلب الثاني \\ الطبيعة القانونية لملحقات الموازنة العامة}

لو القينا نظرة على البنود التي تتضمنها الموازنات العامة لنثاهدنا احكام عامة وقو ائم وجداول بأرقام تقديرية تفصيلية حسب التقاد لتقيمات التي يتم بها تقسيم

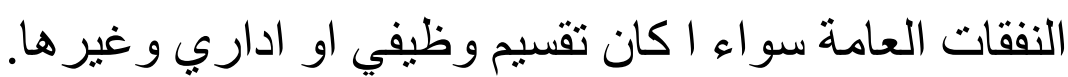
فيمكن القول ان النصوص التي درج على تضمينها هي نصوص اساسية لابد منها لكل موازنة ونصوص التحلق بكيفية تتفيذ الموازنة. و وكذا تتضمن احكام الموازنة العامة بيانات بالنفقات و الاير ادات المتوقعة،

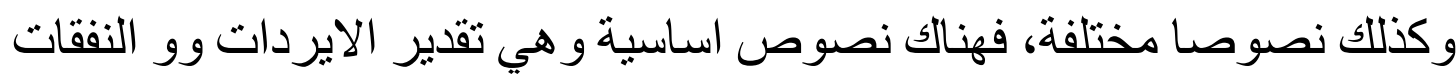

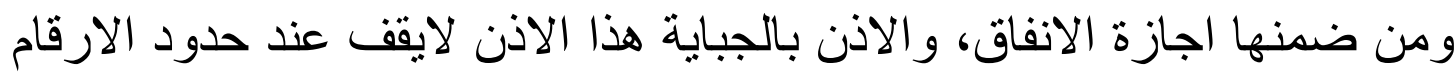

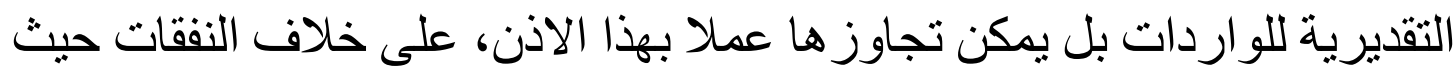

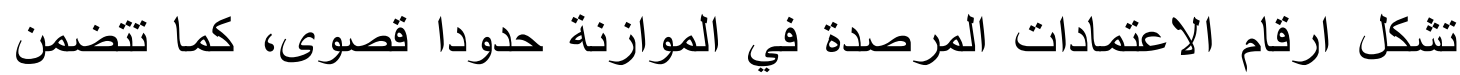

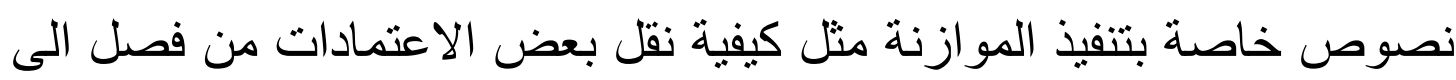

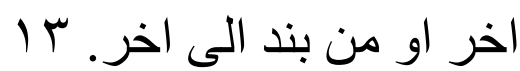
أي ان قانون الموازنة العامة يحتوي على جداول الايردات و النفقات المقدرة

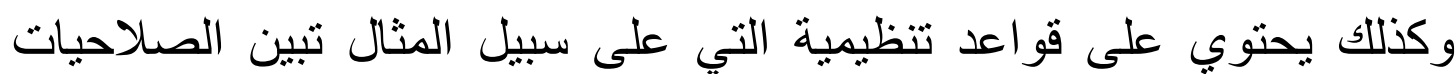
الخاصة لبعض الوزارات بشان الصرف و على الاخص صلاحية وزير المالية.

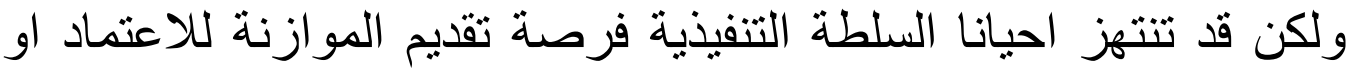

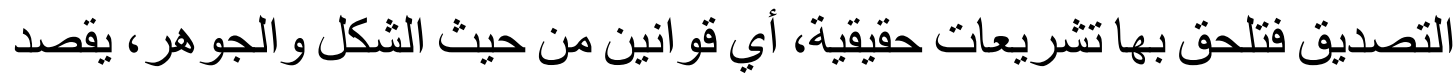




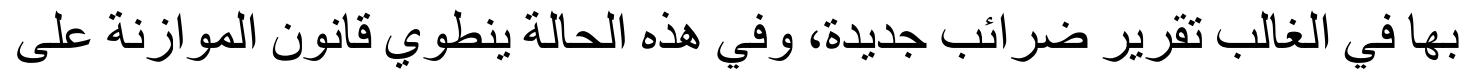

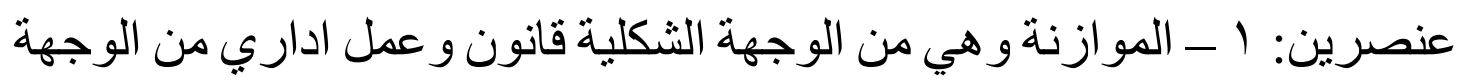

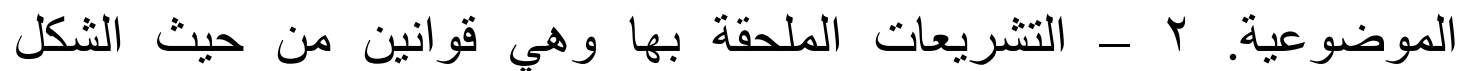
و الموضوع.

فتحاول بعض الدول ان تضمن قانون الموازنة نصوصا لا تتعلق بتتفيذ

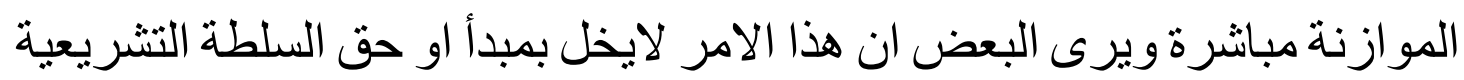
في التشريع. 17

فقد يتضمن مشروع قانون الموازنة نصوصا لا علاقة مبانشرة لها بتنفيذ

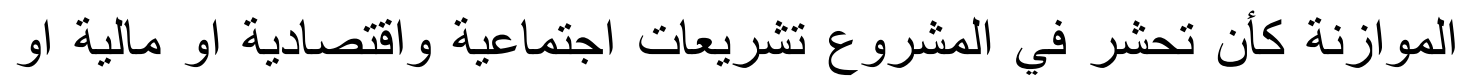

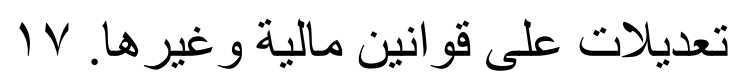

و هكذا نلاحظ ان هذه النصوص المدرجة ضمن بنود الموازنة قد صدرت

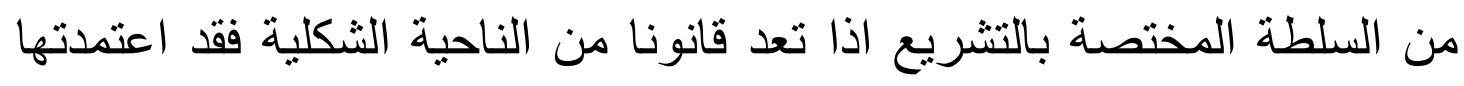

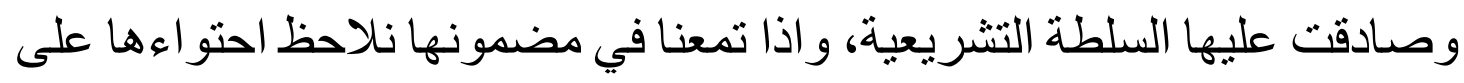

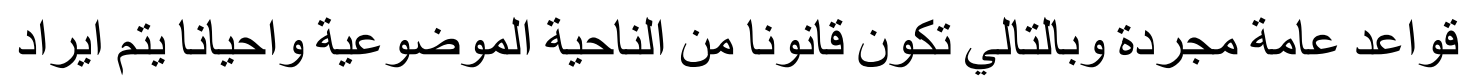

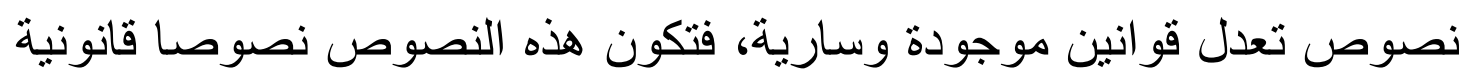

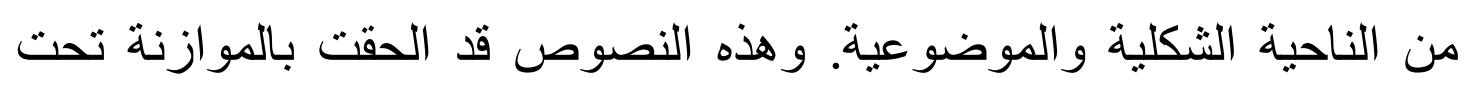
مبررات مختلفة سوف نبينها ونبين مآخذها لاحقا.

\section{المبحث الثناني \\ تمييزمصطلح ملحقات الموازنة العامة عما يشابهها من مصطات وتقينيمها}

المطلب الاول تمييزمصطلح ملحقات الموازنة العامة عما يشابهها من

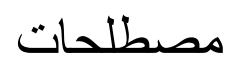

نحاول في هذا المطلب تمييز ملحقات الموازنة عن الموازنة الملحقة وبإيجاز الميز انيات الملحقة 
قد يثير اير اد مصطلح الموازنات الملحقة لبسا مع مصطلح ملحقات الموازنة ولكي نميز بينهما نحاول ان نبين ماهي الموازنات الملحقة (هي ميزانيات الميات الميات

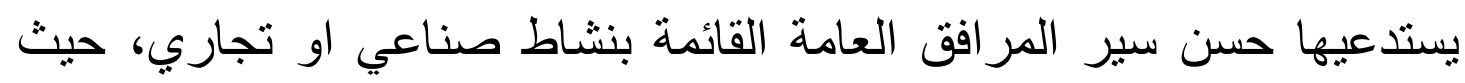

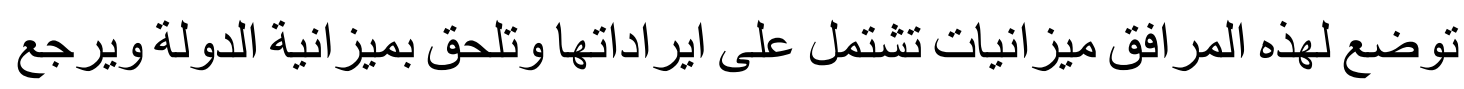

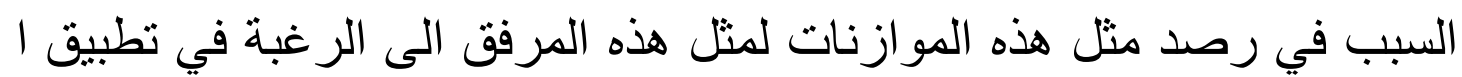

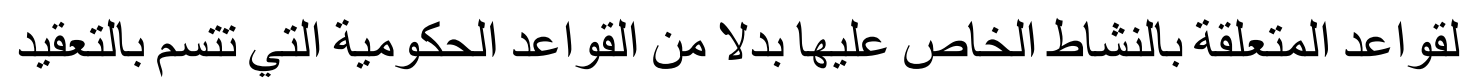

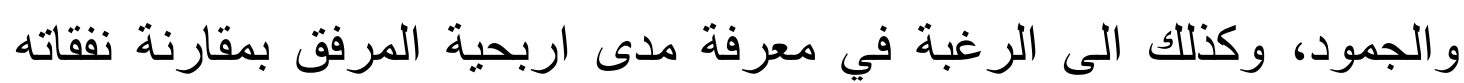

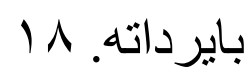

اذ نوضع هذه الموازنات خصيصا لبعض المؤسسات العامة التابعة للدولة و التي ليس لها شخصية معنوية مستقلة عن شخصية الدولة، وتمنح استقلالا ماليا

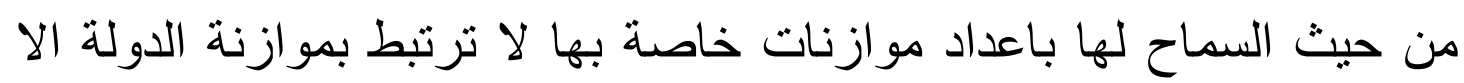

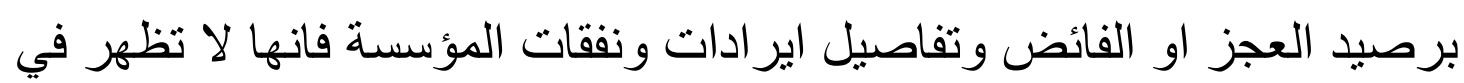
مو ازنة الدولة بل تظهر في موازنتها الخاصة. 19

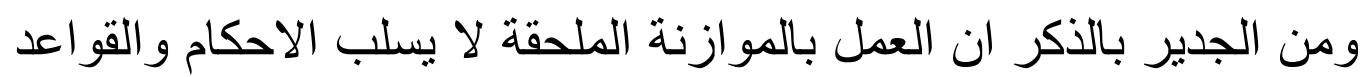

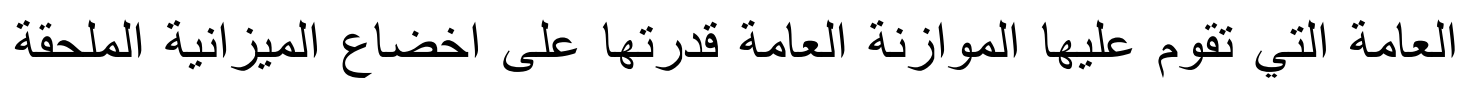

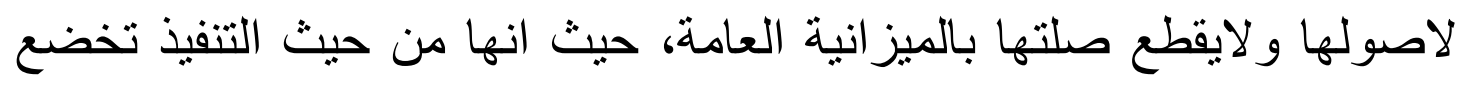

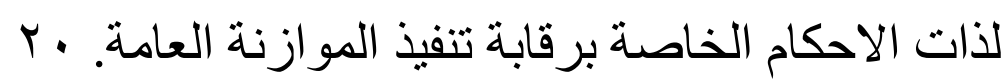

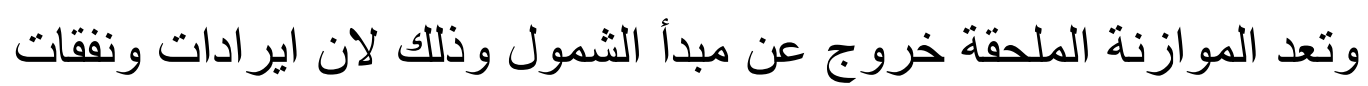

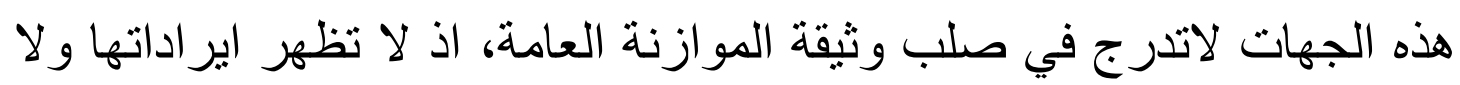

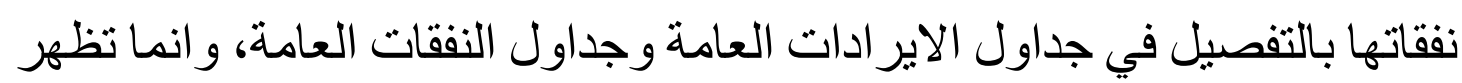

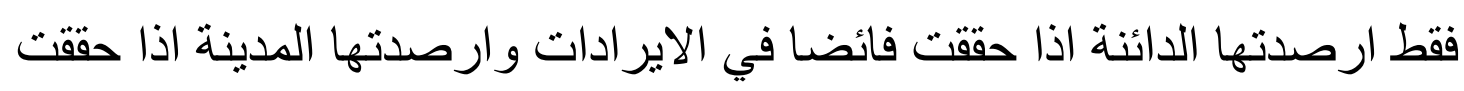

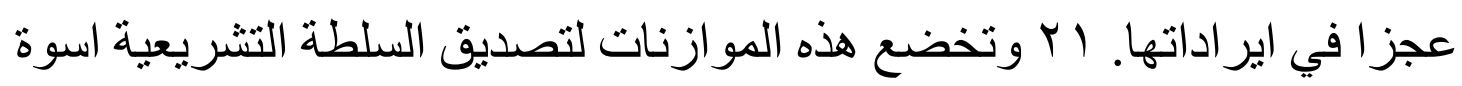

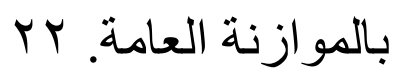
المطلب الثاني تقييم ملحقات الموازنة العامة ضمن تقييم ملحقات الموازنة العامة سنتعرض الى مبررات وسلبيات هذه الملحقات

علمنا ان الحكومة عندما تعرض الموازنة العامة على السلطة التشريعية تحاول احيانا انتهاز هذه الفرصة لاضافة بنود ونصوص الندانة قانونية في الموازنة، 
لكن لماذا تلجأ الى هذه الطريقة هل هناك مبررات لذللك، هل توجد اسباب معينة

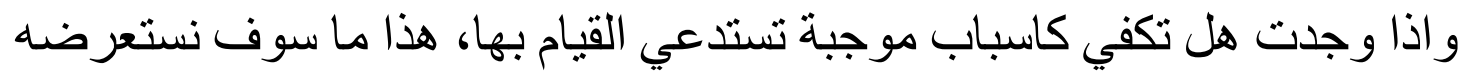
تباعا...

عندما تحاول الحكومة تضمين الموازنة العامة اوجه جديدة للايرادات

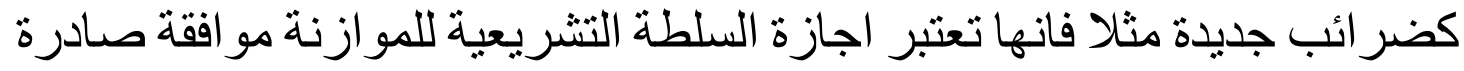

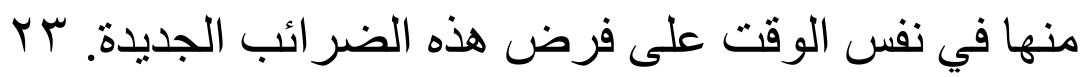

تسلك السلطة التنفيذية هذا الطريق بقصد تسهيل الحصول على موافقة السلطة التشريعية، وتكون مو افقة سهلة، وتتتهز فرصة انعقاد جلسة المجلس. ويتم الحاق القو انين العادية بالميز انية تلافيا للاجر اءات البطيئة التي تمر بها

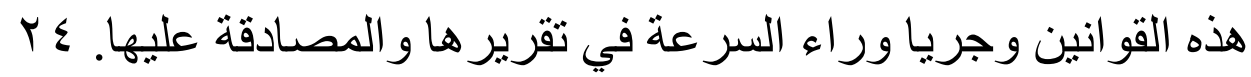
اما من سلبيات هذه الملحقات

انها لا تتيح الوقت الكافي لمناقتة النصوص القانونية و اسبابها ونتائجها. وان التشريعات عموما، وتشريعات الضرائب لما لها من خطورة واهمية وديمومة، لابد وان تصدر في شكل قو انين مستقلة يسهل الرجوع الئرات اليها، وليس في

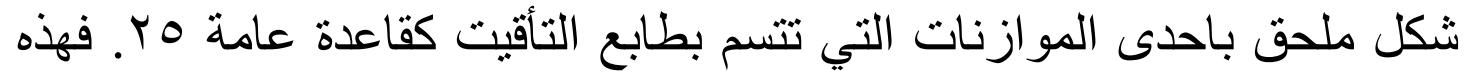

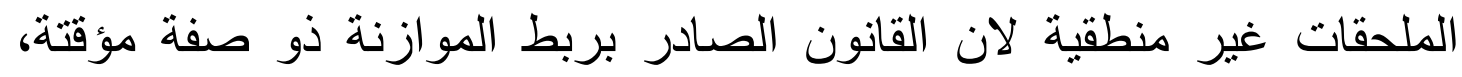
لاتتعدى مدته السنة المالية، وبهذا لايصح ان يتضمن تشريعات التون حقيقية أي عامة ودائمة، و الاعدى مدته

Y-و هذه الملحقات تنطوي على خطورة وذللك لان في العادة تسود روح السر عة

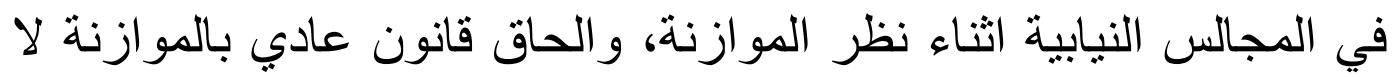

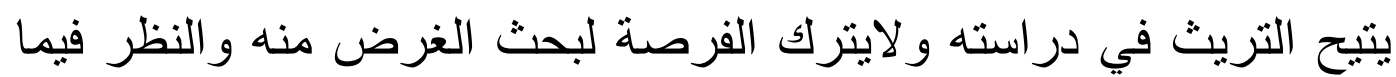

$$
\text { rV بترتب على تقريره من النتائج. }
$$

ب-_يؤدي ادر اج هذه الملحقات الى عدم اتباع الاجر اءات اللازمة لاصدار القانون

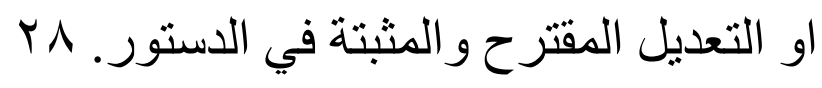

ع-ثم ان تضمين الموازنات سنة بعد اخرى نصوص قو انين حقيقية ثابنة يجعل

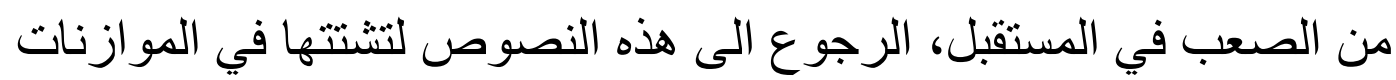
المختلفة. 9 ب المع 


\section{المبحث الثالث}

\section{موقف الاساتير العربية من ملحقات الموازنة العامة \\ ونماذج من الملحقات في بعض الموازنات العامة في لمئي}

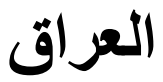

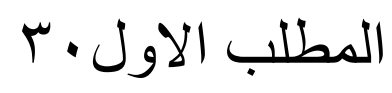

موقف الدساتير العربية من ملحقات الموازنة

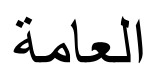

نطلع في هذا المطلب على نماذج من الدساتير العربية التي تطرقت لملحقات الموازنة سواء بشكل مبانشر او غير مباثر وكما يأتي ذكره:

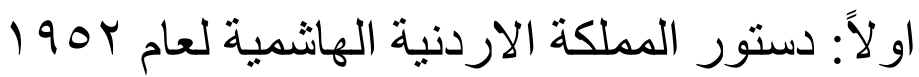

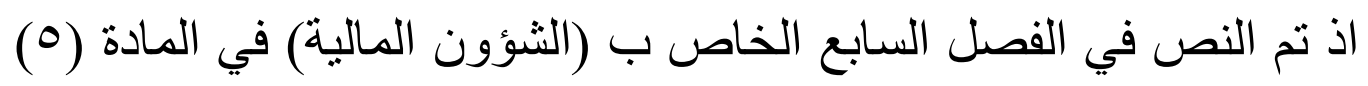

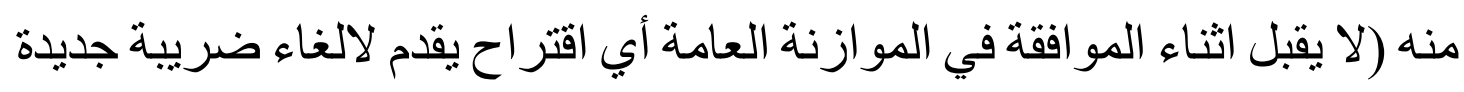

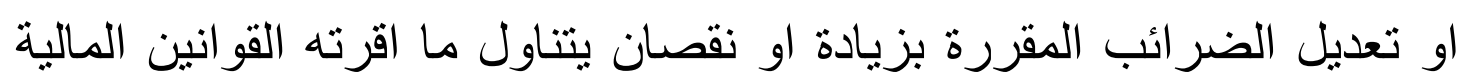

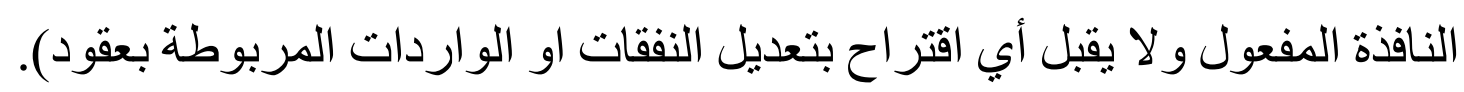

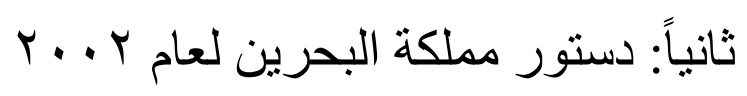

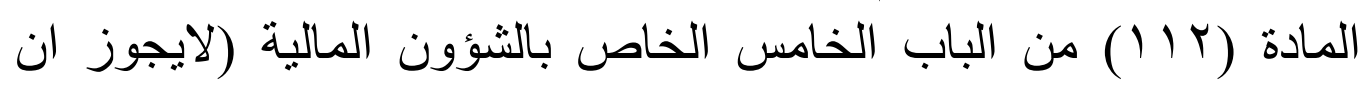

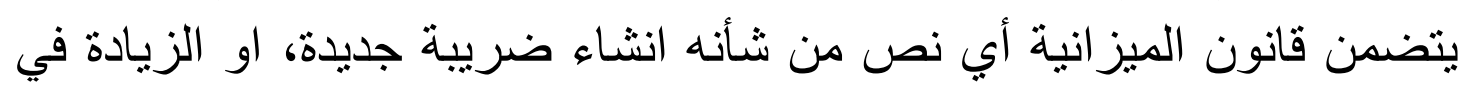

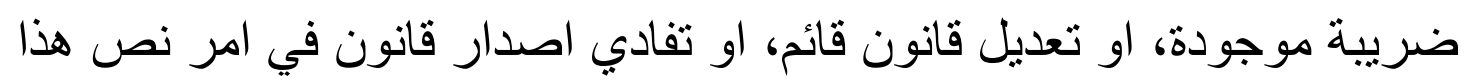
الاستور على ان يكون تنظيمه بقانون).

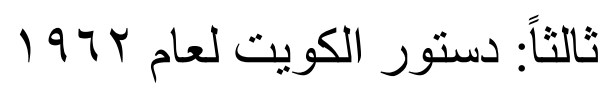

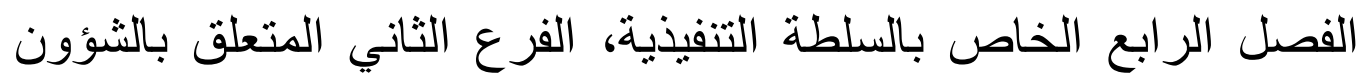

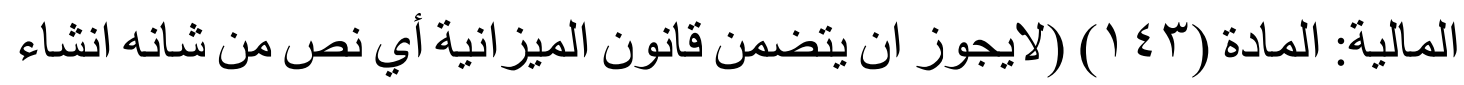

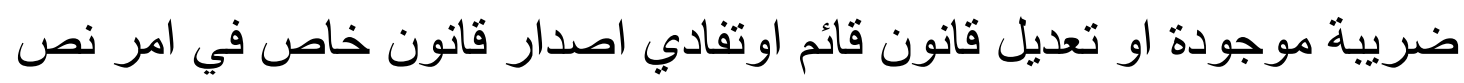
هذا الدستور على وجوب صدور قان فانون في شأنه).

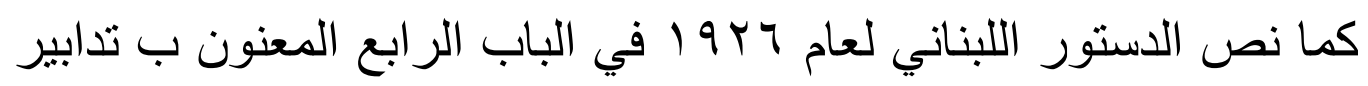

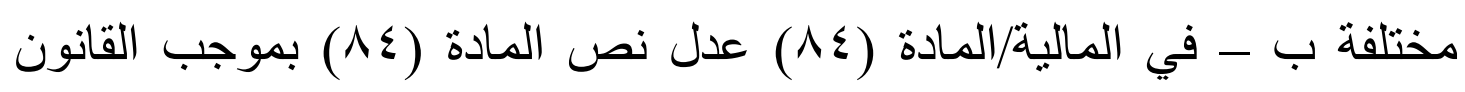




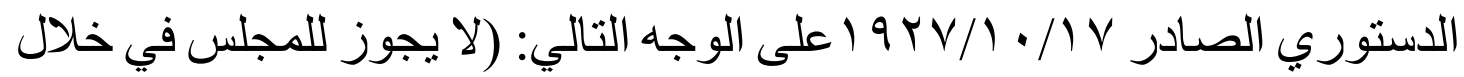

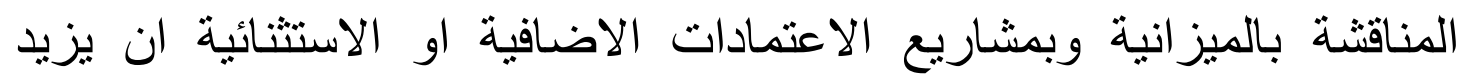
الاعتمادات المقترحة عليه في مشروع الموازنة او في بقية المشاريع المذكورة الأيه

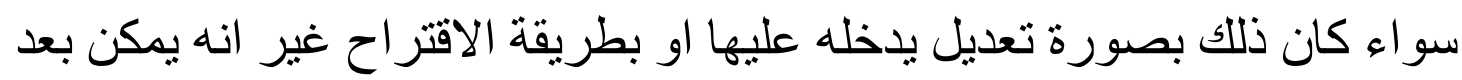

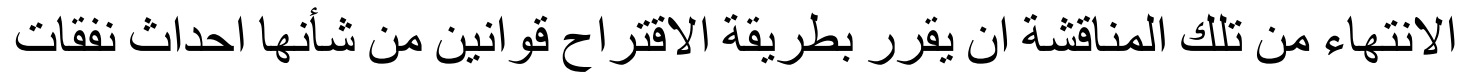

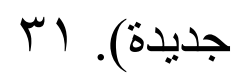

\section{المطلب الثاني}

نماذج عن الملحقات ضمن الموازنات العامة

العر اقبة

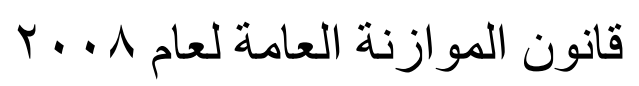

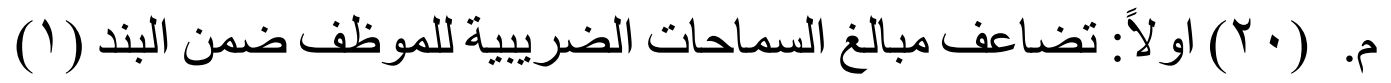

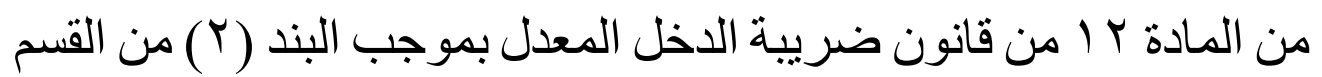

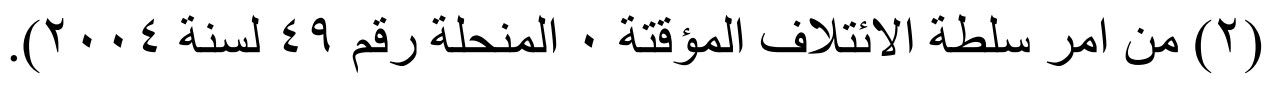
ثانياً: تضاعف المبالغ الخاصة بقياس الضريبة الواردة في المادة با من قانون

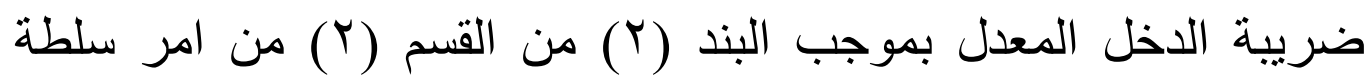

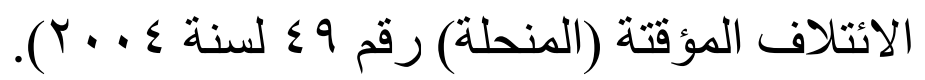

المادة (Yl) (بعفى المقاول الذي تم التعاقد معهد لتنفيذ العقود الجديدة

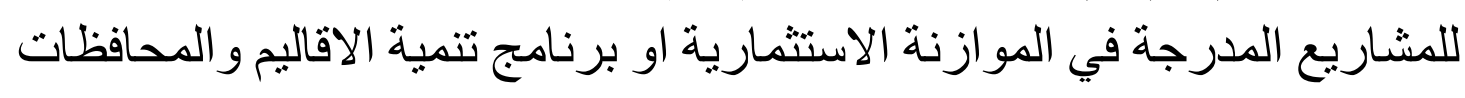

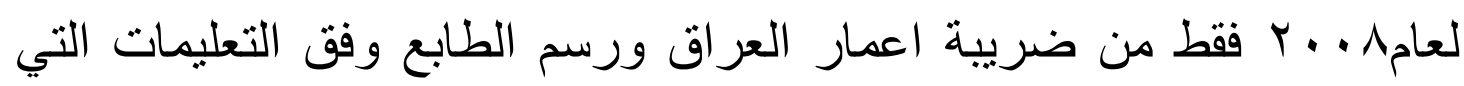

$$
\text { يصدر هاوزير المالية). }
$$

قانون الموازنة العامة الاتحادية لجمهورية العر اق للسنة المالية | 1 ـ ب م. (Y9) منع تأجير الطائر ات بشكل مطلق على حساب الدولة للجهات كافة

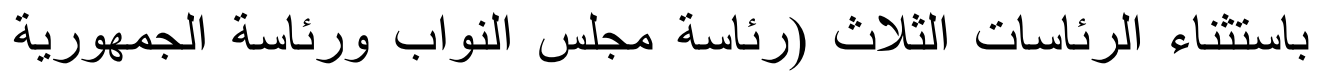

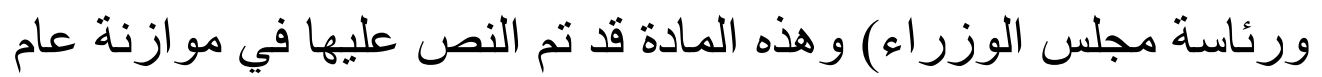

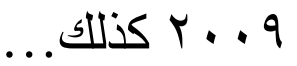

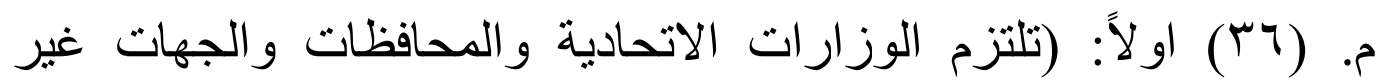

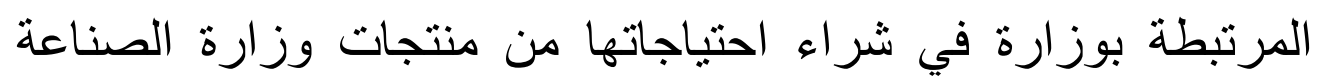


و المعادن الاتحادية على ان لاتقل القيمة المضافة لهذه المنتجات (•r\%)

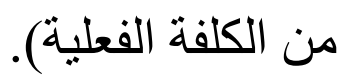

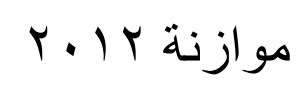

المادة (؟ ب) تعفى البضائع و السلع الممنوحة لدو ائر الدولة والقطاع العام من حكومات ومؤسسات مانحة من الرسوم الكمركية.

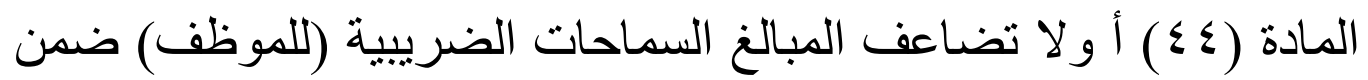

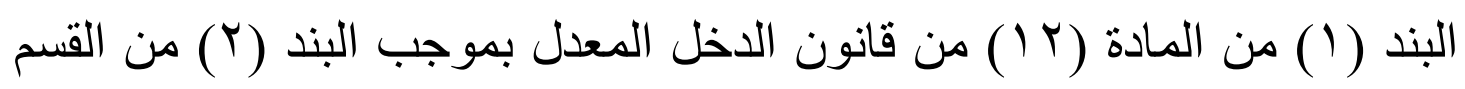

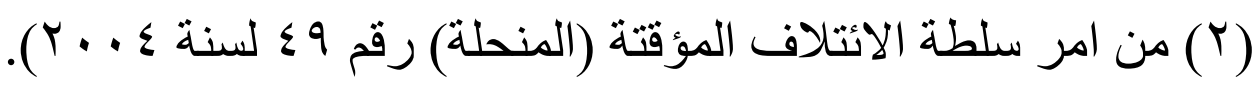
ثانياً: تضاعف المبالغ الخاصة بقياس الضريبة الواردة في المادة بـ إ من قانون

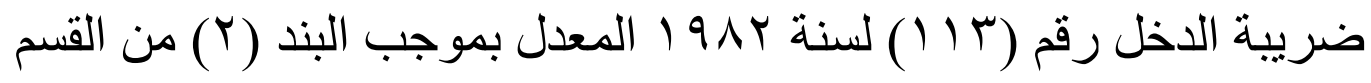

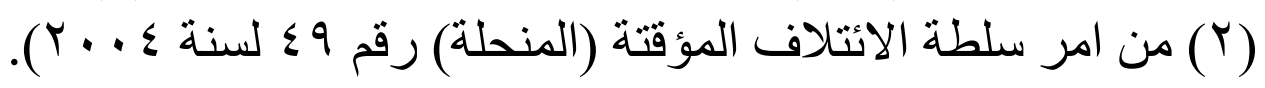

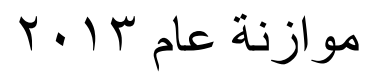

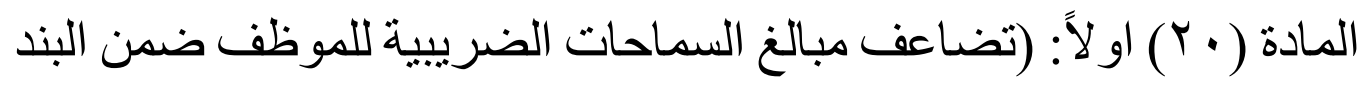

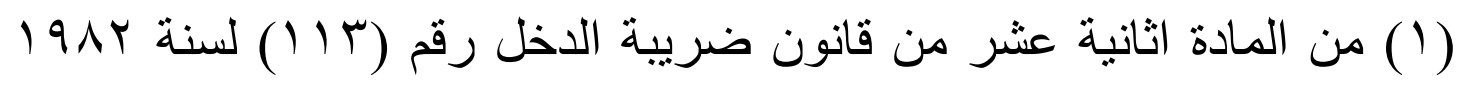

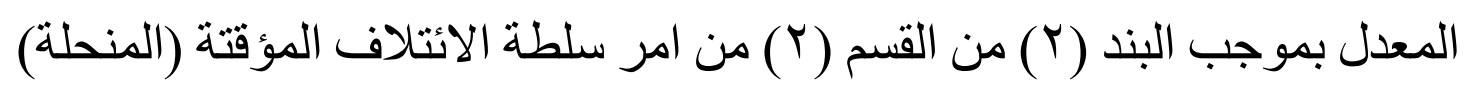

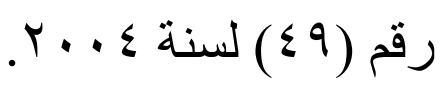

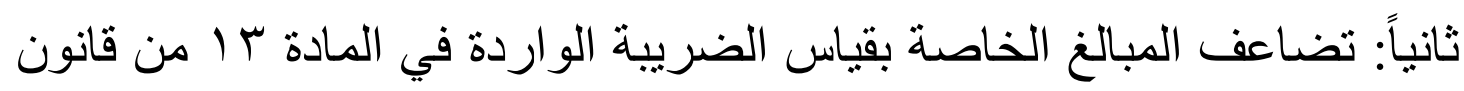

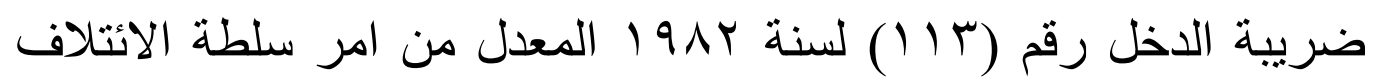

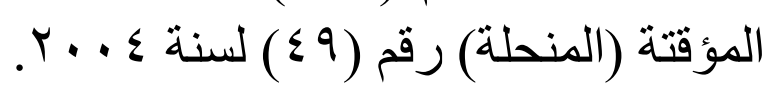

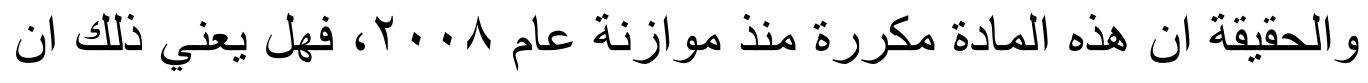

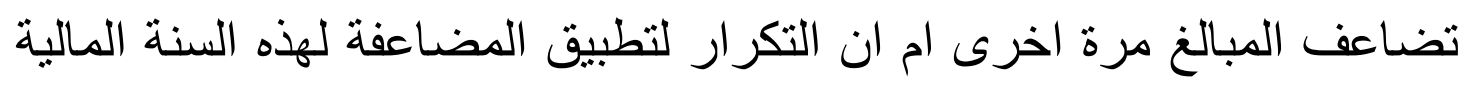

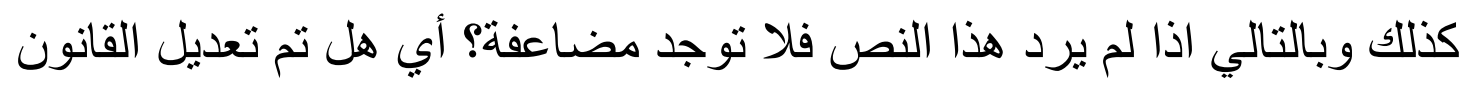

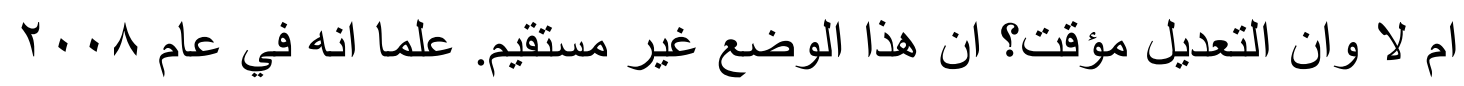

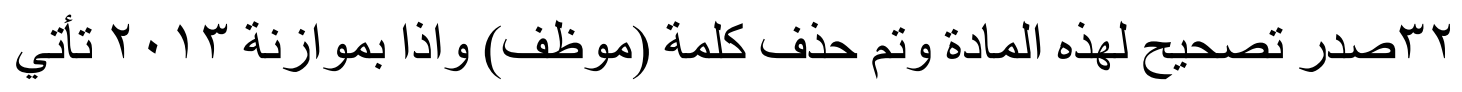

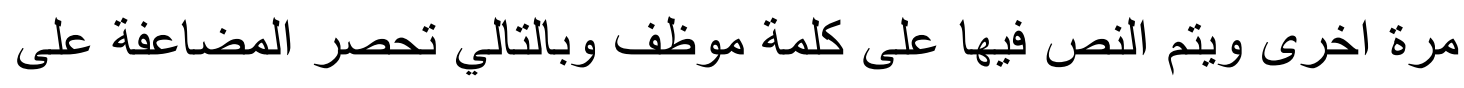
الموظف فقط، ام سيصدر تصحيح اخر؟ هذه الامور تثير اللبس و الغموض لذا ينطلب الابتعاد عن تعديل القو انين بهذه الطريقة واصدار التعديلات بالطرق القانونية السليمة. 
المادة (rآج) اولاً: (تعفى من الرسوم كافة البضائع و السلع المستوردة من قبل دو ائر الدولة والقطاع العام باسمها ولاستخدامها. ثانياً: (يشمل الاعفاء اعلاه البضائع و السلع المستوردة لدو ائر الدولة و القطاع العام

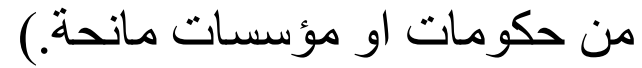




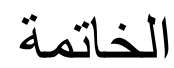

في هذا البحث الموجز حاولنا تسليط الضوء على موضوع مهم تتضمنه

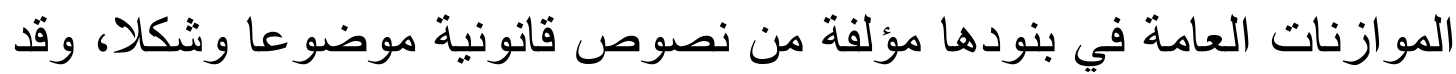

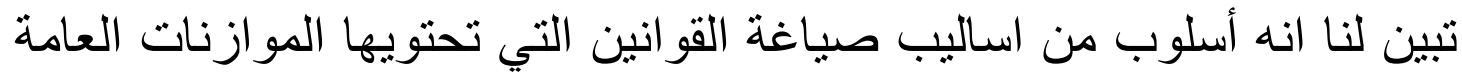

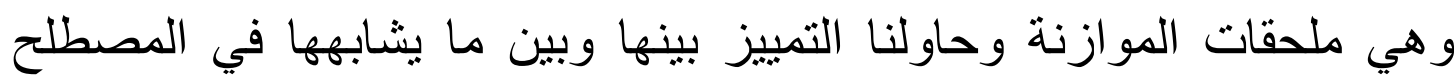

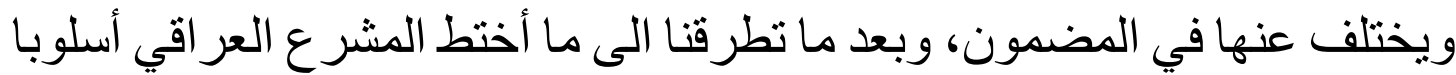

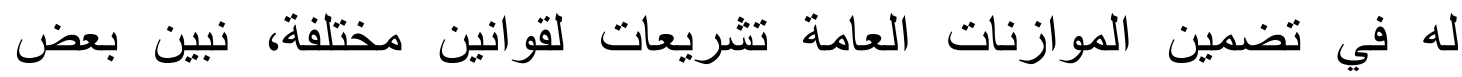
الاستتناجات ونقام بعض التوصيات منها

او لاً: بعد اطلاعنا على بعض الموازنات العامة في العر اق لاحظنا انها تضمنت

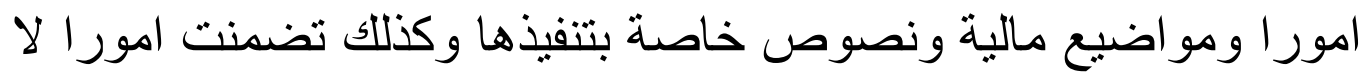

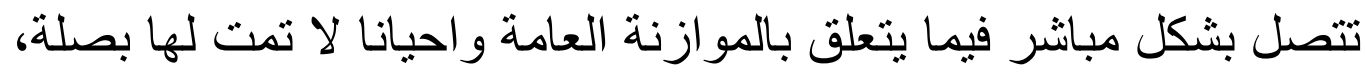

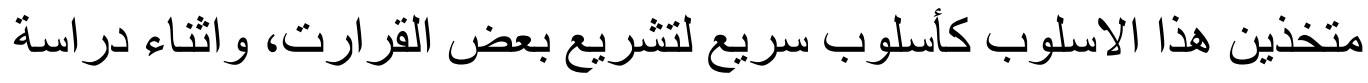

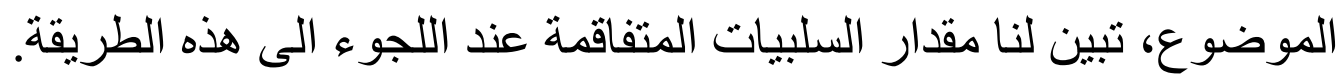

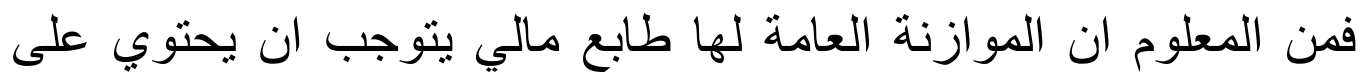

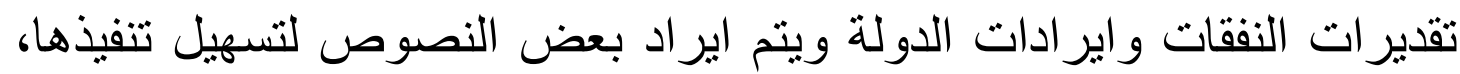

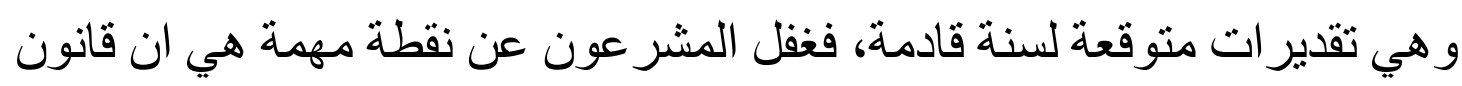

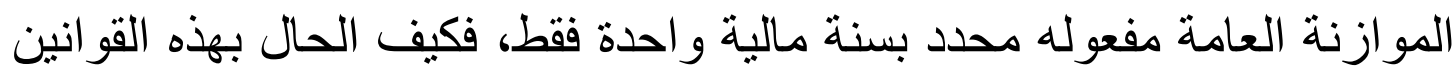
وتعديلات القو انين التي نر افق الموازنة وكأنها قرارات مشر عنة.

لذا يستوجب اضافة نص الى الدستور العراقي يمنع اللجوء الى ملحقات الموازنة شأنه في ذللك شأن الدساتير العربية.

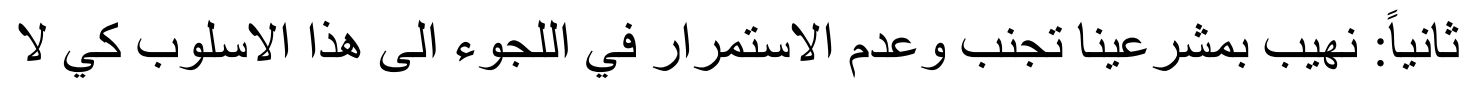

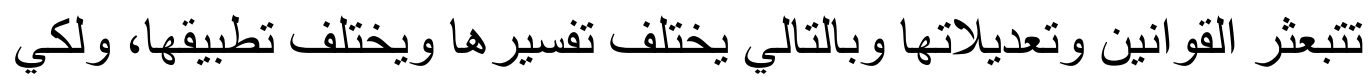

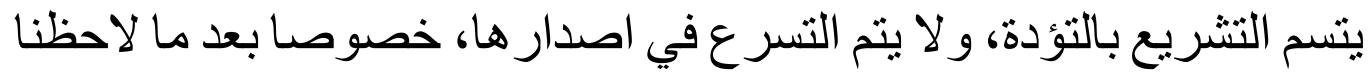

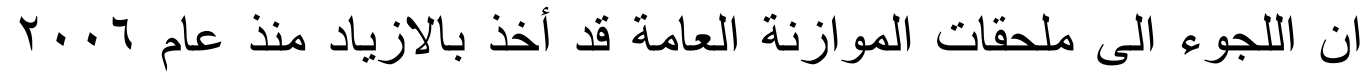
واخذت تتمو وتتمو دون توقف. 
ثالثاً: ونقتر ح بدلا من ان يتم الحاق قو انين بالموازنة من المهم ان تلحق بها مذكرة

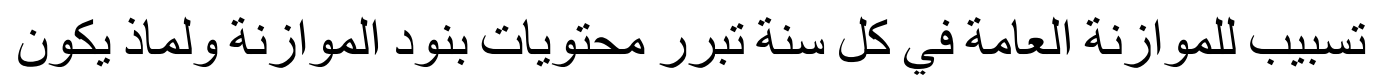

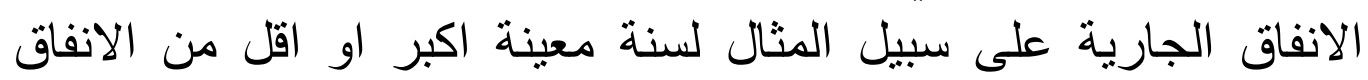

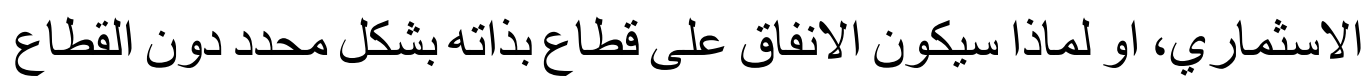

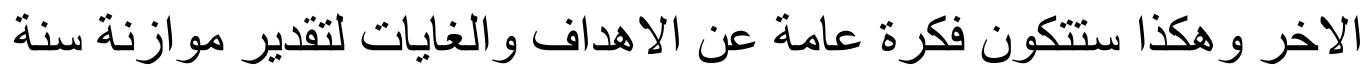

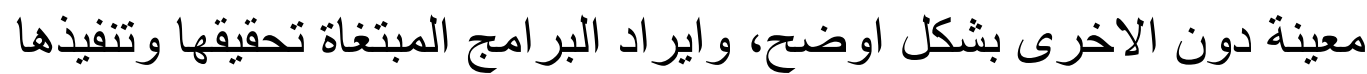

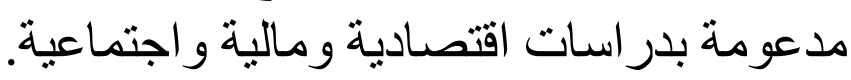


المصادر

الكتب

د. ابر اهيم عبد الكريم الغازي، التشريع المالي في الميز انية العامة للدولة،

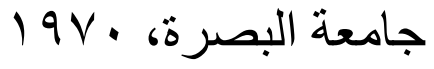

الدساتير العربية ودر اسة مقارنة بمعايير الحقوق الدستورية الدولية، الطبعة

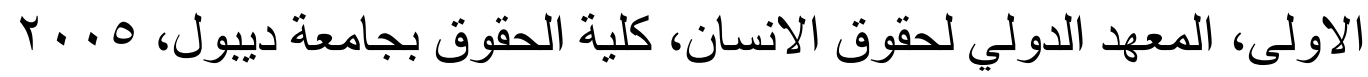

د. خالد شحادة الخطيب، د. احمد زهير شامية، أسس المالية العامة، الطبعة

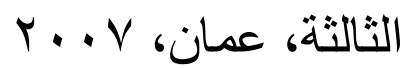

د. خطار شلبي، الغلوم المالية/الموازنة العامة، طبعة ثالثة منقحة، دار الكتاب اللبناني، بيروت،

سوزي عدلي، المالية العامة، منشورات الحلبي الحقوقية، بيروت، بدون

د. عبد العال الصكبان، الميز انية والضرائب المباثرة في العراق، الطبعة

الاولى، مطبعة العاني، بغداد، $197 \mathrm{~V}$

د. محمد شاكر عصفور، أصول الموازنة العامة، الطبعة الثانية، دار

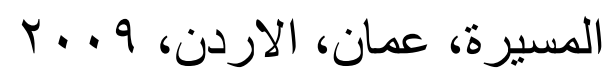

مصطفى القوني، المالية العامة و الضر ائب، مكتبة الانجلو مصرية، القاهرة،

هاثُم الجعفري، مبادئ المالية العامة والتشريع المالي، مطبعة سلمان

الاعظمي، (197)

د. يونس أحمد البطريق، د. حامد عبد المجيد، د. سعبد عبد العزيز، مبادئ

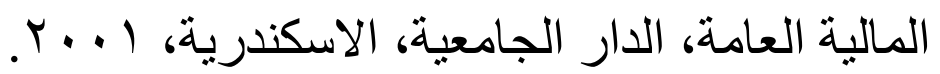

الدساتبر

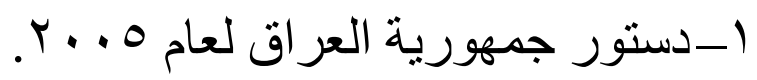




$$
\begin{aligned}
& \text { Y-دستور المملكة الاردنية الهاشتمية. } \\
& \text { r-_دستور مملكة البحرين لعام Y . . . . }
\end{aligned}
$$

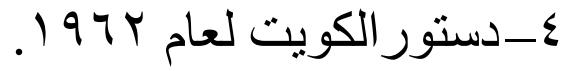

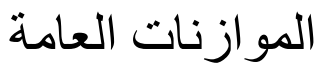

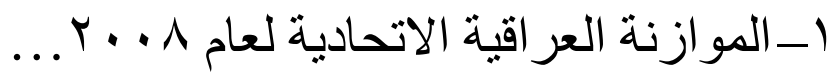

$$
\begin{aligned}
& \text { r_ الموازنة العر اقية الاتحادية لعام | I ... } \\
& \text { r_الموازنة العر اقية الاتحادية لعام r ا • r. }
\end{aligned}
$$

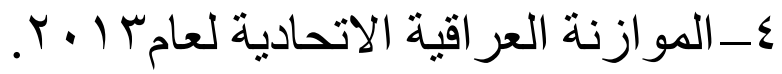

\section{الهو امث}

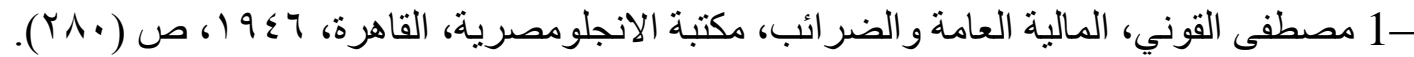

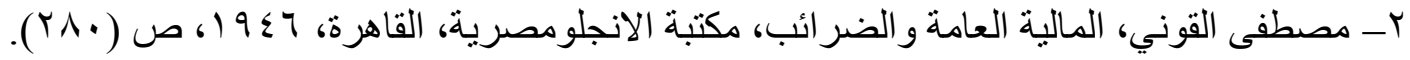
بـ د. خطار شلبي، الغلوم المالية/الموازنة العامة، طبعة الثالثة الثة منقحة، دار الكتاب اللبناني، بيروت،

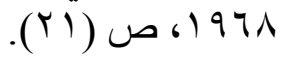
ع- د. خطار شلبي، العلوم المالية/الموازنة العامة، طبعة ثالثة منقحة، دار الكتاب اللبناني، بيروت،

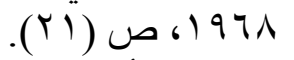

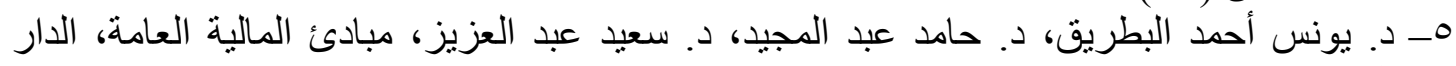

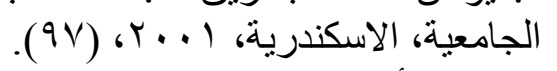
T- د. يونس أحمد البطريق، د. د. حامد عبد المجيد، د. سعيد عبد العزيز، مبادئ المالية العامة، المصدر

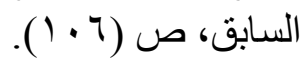

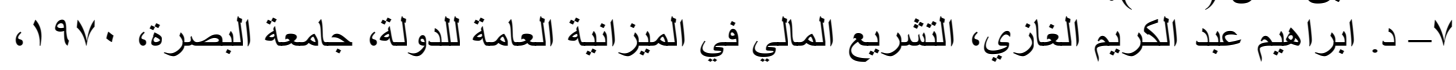

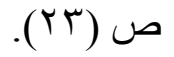

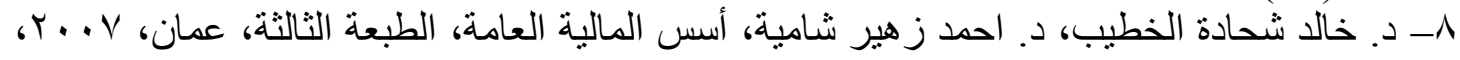
ص (rVO)

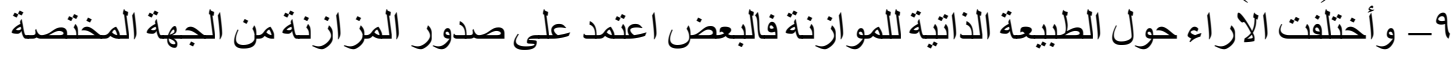

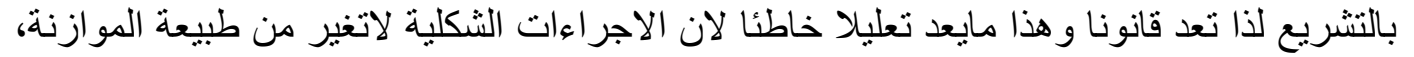

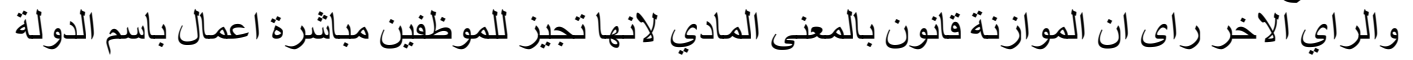

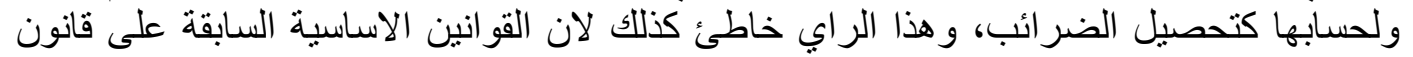

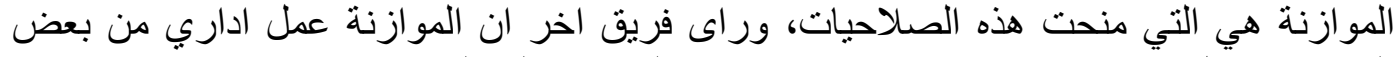

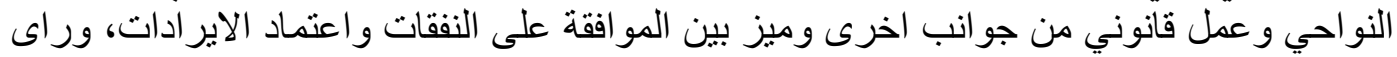

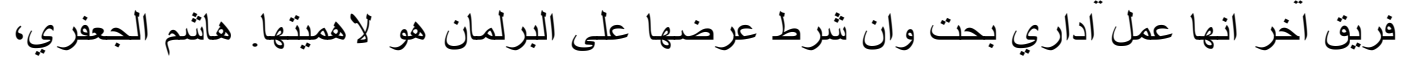

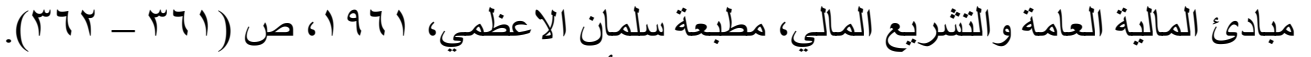

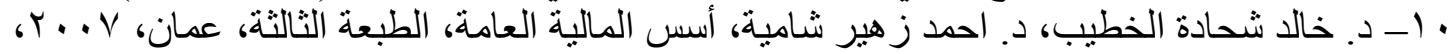




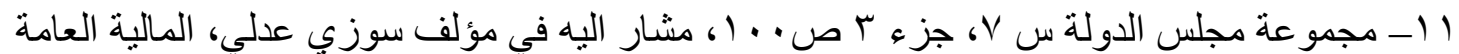

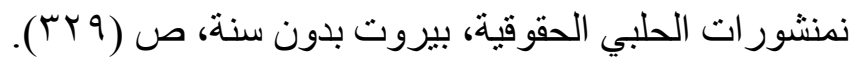

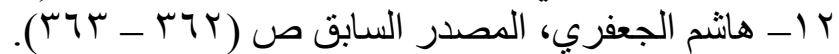

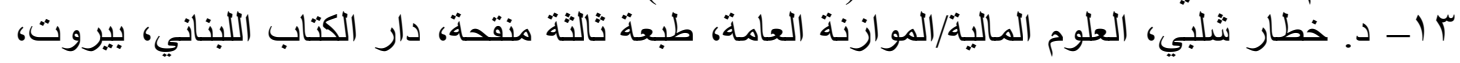

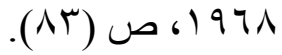

ع ا ـ ابر اهيم عبد الكريم الغازي، التشريع المالي في ميز انية العامة للدولة، المصدر السابق، ص (Y Y I ).

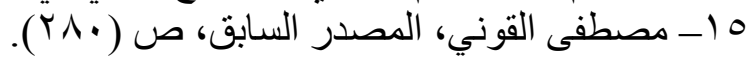

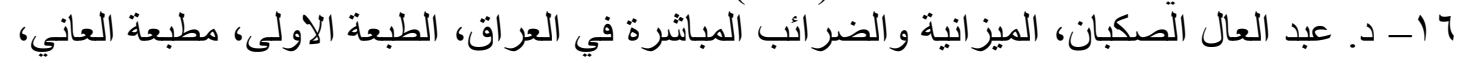

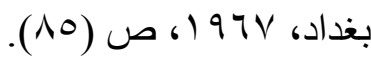

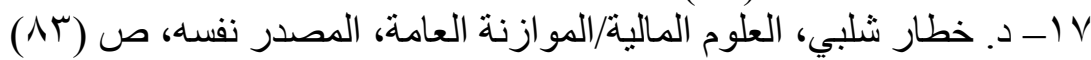

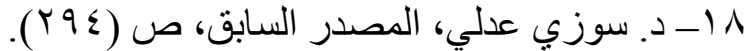

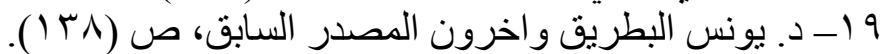

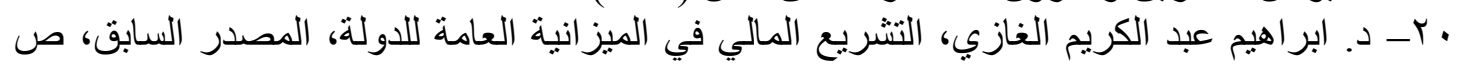
ا Yـ د. محمد شاكر عصفور، أصول الموازنة العامة، الطبعة الثانية، دار المسيرة، عمان، الاردن،

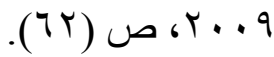

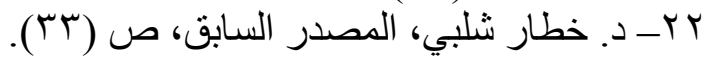

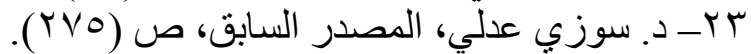

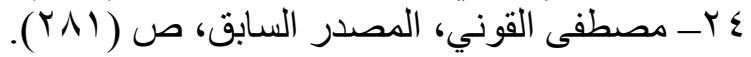

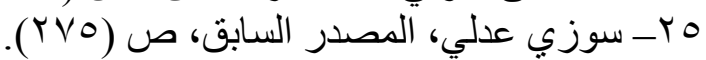

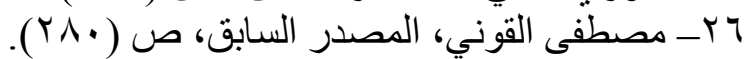

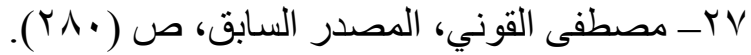

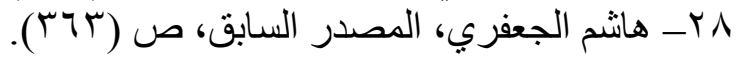

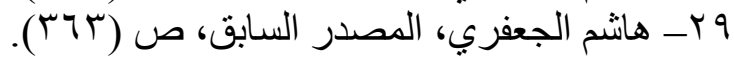

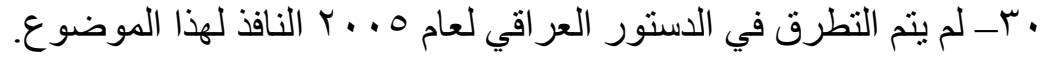

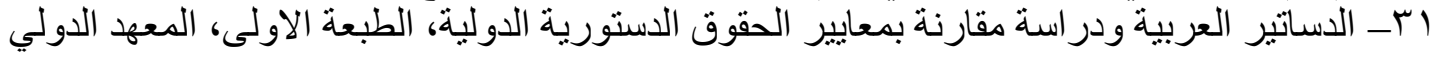

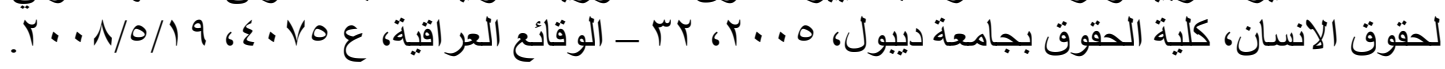

